\title{
Characterization and textural analysis of Middle Bronze Age Transdanubian inlaid wares of the Encrusted Pottery Culture, Hungary: a preliminary study
}

\author{
S. Roberts ${ }^{\mathrm{a}, *}$, J. Sofaer ${ }^{\mathrm{b}}$, V. Kiss ${ }^{\mathrm{c}}$ \\ ${ }^{a}$ School of Ocean and Earth Science, National Oceanography Centre, University of Southampton, Southampton, SO14 3ZH, UK \\ ${ }^{\mathrm{b}}$ School of Humanities, University of Southampton, Southampton, SO17 1BF, UK \\ ${ }^{\mathrm{c}}$ Hungarian Academy of Sciences, H-1250 Budapest, Hungary
}

Received 25 January 2007; received in revised form 26 March 2007; accepted 27 March 2007

\begin{abstract}
Inlaid ceramics belonging to the Encrusted Pottery Culture and dated to the Middle Bronze Age (2000-1500 BC) are highly distinctive vessels with complex decorative motifs found in large numbers in the Transdanubia region of Hungary. Despite this considerable corpus of material there has been little systematic investigation of the composition of the inlays. Micro-analysis of Transdanubian inlaid wares by X-ray diffraction (XRD), micro-Fourier transform infrared microscopy (FT-IR), and scanning electron microscopy (SEM) provides new compositional, structural and textural information on the inlays. In contrast to common statements in the literature regarding the materials used to make inlays, these new data show that the majority of inlays are composed of hydroxyapatite (bone) that was previously ashed, although some of the inlays are composed of calcium carbonate. Additional compositional and textural variation in the bone inlays suggests that bone material from different skeletal elements and/or of different age may have been used, and that contrasting recipes for inlay preparation were employed during fabrication. These results suggest that the production of inlaid vessels of the Encrusted Pottery Culture was more complex than has hitherto been thought.
\end{abstract}

(C) 2007 Elsevier Ltd. All rights reserved.

Keywords: Bronze Age; Pottery; Inlay; Bone; Hydroxyapatite; Ceramics; FTIR

\section{Introduction}

The Middle Bronze Age Encrusted Pottery Culture in Transdanubia, Hungary (2000-1500 BC) is named after the highly distinctive inlaid ceramic vessels that are found in large numbers in this region. The vessels have a range of complex decorative motifs including rouletting, zigzags, combing, hashing, lines, dots, circles, banding and herringbone patterns that may occur either singly or in combination, and that are typically filled with white inlay (Bóna, 1975).

Despite the large quantity of available material and its visually striking nature, little attention has previously been paid to

\footnotetext{
* Corresponding author.

E-mail address: sr1@noc.soton.ac.uk (S. Roberts).
}

the composition of Encrusted Pottery Culture inlays or the technologies involved in their production. Previous studies of the ceramics of the Encrusted Pottery Culture and its immediate precursor the Early Bronze Age Kisapostag Culture (2100-2000 BC), as well as of other contemporary Bronze Age cultural groups in Hungary, Croatia, Slovakia, and Romania where inlaid vessels have also been found, have focussed on shape and decoration in the construction of local chronologies (Bóna, 1975; Kiss, 2003; Šimić, 2000). This has formed the basis for the division of inlaid vessels into typological groups.

In Transdanubia, Kisapostag ceramics, have a typical 'rolled-stick' decoration (Torma, 1978). Subsequent developments see the emergence of a northern Encrusted Pottery group along the shores of Lake Balaton and to the north of the lake, while southern Encrusted Pottery Culture types are found in the region bordered by the rivers Sió, Kapos and 
Danube, and by the Mecsek hills (Kiss and Somogyi, 2004) (Fig. 1). Northern types have shallow inlays without a distinct bed prepared for the decoration. The decoration is placed on the belly or neck of vessels and is rather simple in form, the most common patterns being dashed lines, horizontal ribbing, dots, and dots within circles. The latter may be arranged into a flower motif. Southern types are characterised by deeper inlays placed in a broad bed. Complex decorative elements cover most of the surface of the vessel and are arranged in a vertical and horizontal system. Motifs include zigzags, corded decoration, combed decoration in the form of arches, hashing, and incised M-patterns (Bóna, 1975). On the grounds of their elaboration and fineness, inlaid vessels of the Encrusted Pottery Culture are commonly suggested to have been manufactured in a restricted number of workshops that mass-produced vessels (Bóna, 1975), their wider distribution outside Transdanubia occurring as a result of utilization in regional exchange systems (Bóna, 1975; Fischl et al., 1999; Kiss, 2002). However, no such pottery workshops have yet been located and excavated. North and south groups of the Encrusted Pottery Culture also display differences in burial tradition. While the predominant rite in both groups is cremation, in the north they are frequently placed in urns, while in the south they are commonly un-urned deposits placed directly in the ground (Bóna, 1975).

The literature on Encrusted Pottery Culture vessels commonly refers to the inlays as being made of lime or powdered shell (Bóna, 1975; Kiss, 2003). To date there has been little systematic investigation of inlay composition and none of inlay texture. Nonetheless, the few studies of individual prehistoric inlaid sherds dating from the Neolithic to the Iron Age in Hungary and elsewhere in Central Europe indicate a range of possible inlay materials including birch bark, bone, plant fibres, shell (calcite), gypsum, kaolin and chalk (Csengeri, 2001; Gherdan et al., 2003; Sziki et al., 2002; Trachsler, 1966; Uzsoki, 1959; Wosinsky, 1904). Using electron microprobe analysis Gherdan et al. (2003) found that inlay sampled from the Kisapostag site of Vörs had a high calcium and phosphorous content which under further inspection, using XRD, proved to be hydroxyapatite (bone). Recent research on Encrusted Pottery Culture material using $\mu$-PIXE described the inlay in a sherd from the site of Balatonfüzfö, a site in the northern group of the Encrusted Pottery Culture, as having a high calcium and carbon content (Sziki et al., 2002). Earlier, Uzsoki (1959) compared the chemical composition of potential inlays including calcined bone and shell to suggest that inlay from the Mosonszentmiklós cemetery, also in the northern group, was composed of a mixture of shell and ashed bone.

Here we present new X-ray diffraction (XRD), Fourier transform infrared (FT-IR) microscopy, and scanning electron microscopy (SEM) data on the compositional, structural and textural characteristics of Transdanubian Encrusted Pottery Culture inlays. These new data suggest that techniques used to make Middle Bronze Age Transdanubian inlays are variable, involving substantially different recipes and inlay preparation techniques, with different chemical composition and textural characteristics.

\section{Materials}

Samples were analysed from five settlements and one cemetery site in Transdanubia, Hungary, including material from the Kisapostag phase and both northern and southern groups of the Encrusted Pottery Culture (Table 1; Fig. 1). Kisapostag

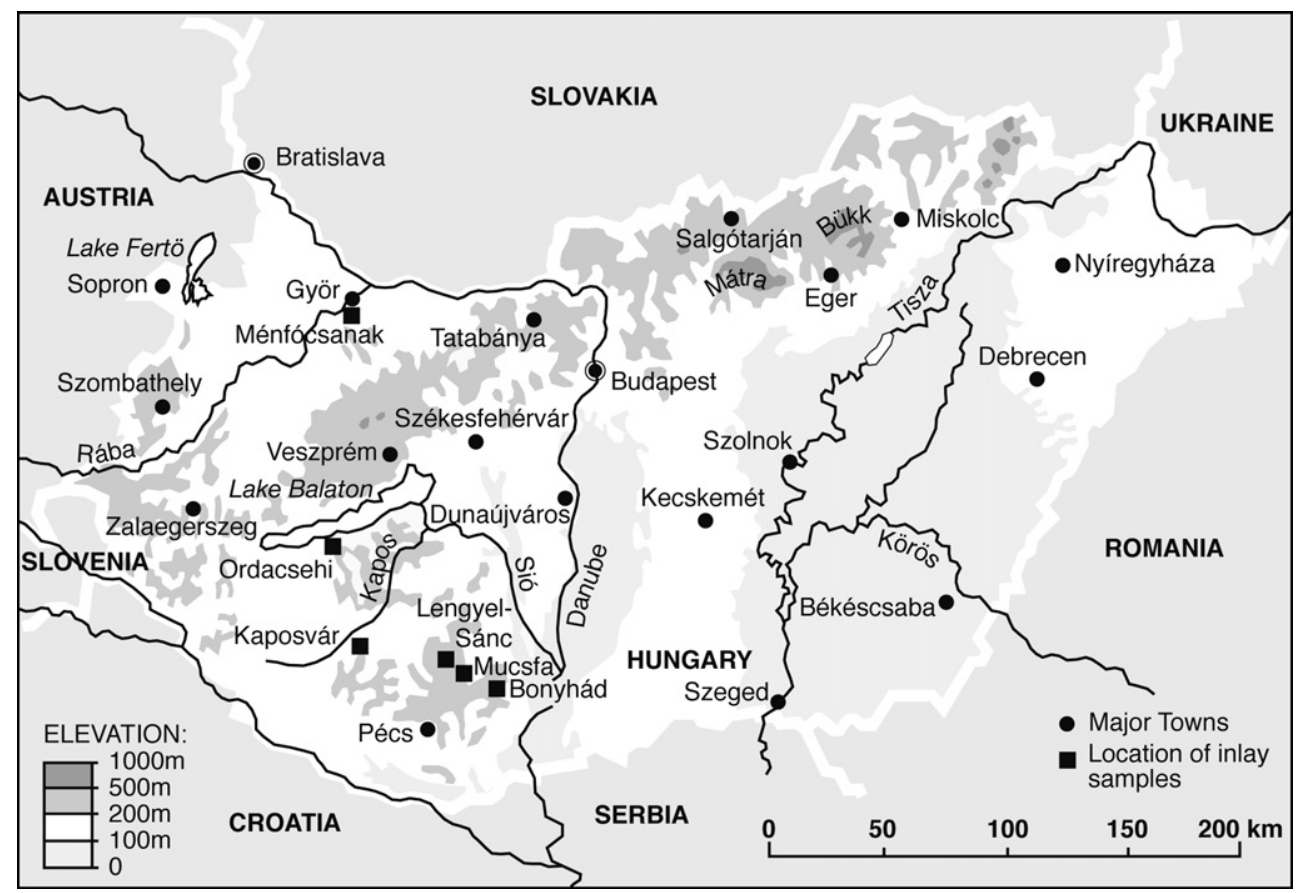

Fig. 1. Topographic map of Hungary with locations of major cities and sites for the inlaid pottery investigated in this study. 
Table 1

Summary of sample sites, number of samples analysed, site type (settlement or cemetery) and Encrusted Pottery Culture phase and group (Kisapostag, north or south)

\begin{tabular}{|c|c|c|c|}
\hline Site & $\begin{array}{l}\text { No. of } \\
\text { samples }\end{array}$ & Site type & Phase and group \\
\hline Bonyhád & 1 & Settlement & Kisapostag \\
\hline Ordacsehi & 1 & Settlement & Kisapostag \\
\hline Mucsfa & 2 & Settlement & $\begin{array}{l}\text { South Encrusted } \\
\text { Pottery Culture }\end{array}$ \\
\hline Lengyel-Sánc & 3 & Settlement & $\begin{array}{l}\text { South Encrusted } \\
\text { Pottery Culture }\end{array}$ \\
\hline Kaposvár & 6 & Settlement & $\begin{array}{l}\text { North Encrusted } \\
\text { Pottery Culture }\end{array}$ \\
\hline Ménföcsanak & 1 & Cemetery & $\begin{array}{l}\text { North Encrusted } \\
\text { Pottery Culture }\end{array}$ \\
\hline
\end{tabular}

material came from the settlement sites of Bonyhád in the southern part of the region and Ordacsehi in the northern part of Transdanubia. The southern group of the Encrusted Pottery Culture was represented by sherds from settlements at Mucsfa and Lengyel-Sánc, while the northern group was represented by material from Kaposvár and Ménföcsanak. Kaposvár is the largest excavated settlement of the northern group. It is situated close to the typological border with the southern group and yielded sherds belonging to both northern and southern types (Kiss and Somogyi, 2004). Ménföcsanak is one of the largest cemeteries of the northern Encrusted Pottery group with over 140 cremations known from the site (Kiss, 2004). Examples of the inlaid sherds analysed are shown in Fig. 2.
The surface geology at all sites is very similar, reflecting the relatively homogenous surface geology of Transdanubia, with deposits of loess found at all sites investigated. Outcrops of Jurassic-Triassic limestones occur $20 \mathrm{~km} \mathrm{~S}$ of Kaposvar and along the northern shores of Lake Balaton. There are, however, differences in the vegetation zones between north and south Encrusted Pottery groups. The northern group is in a region of central European mixed woodlands, while the southern group lived among sub-Mediterranean oak woods (Sümegi and Bodor, 2000).

\section{Methods}

\subsection{X-Ray diffraction}

Individual samples of inlay were liberated using a scalpel to avoid contamination by the host paste and typically $40 \mathrm{mg}$ of inlay were powdered in an agate pestle and mortar, loaded on a silicon disc holder and analysed on a Philips XPert Pro diffractometer using a cobalt tube powered at $35 \mathrm{kV}$ and $35 \mathrm{~mA}$ from 2 to 75 degrees $2 \theta$. This procedure was then repeated for separate samples of the host paste. The diffractograms were interpreted using Philips software and the JCPDS-International Centre for Diffraction Data Library.

\subsection{Fourier transform infrared microscopy}

For FT-IR analyses a few milligrams of inlay was liberated from each sample using a scalpel blade, to ensure that only
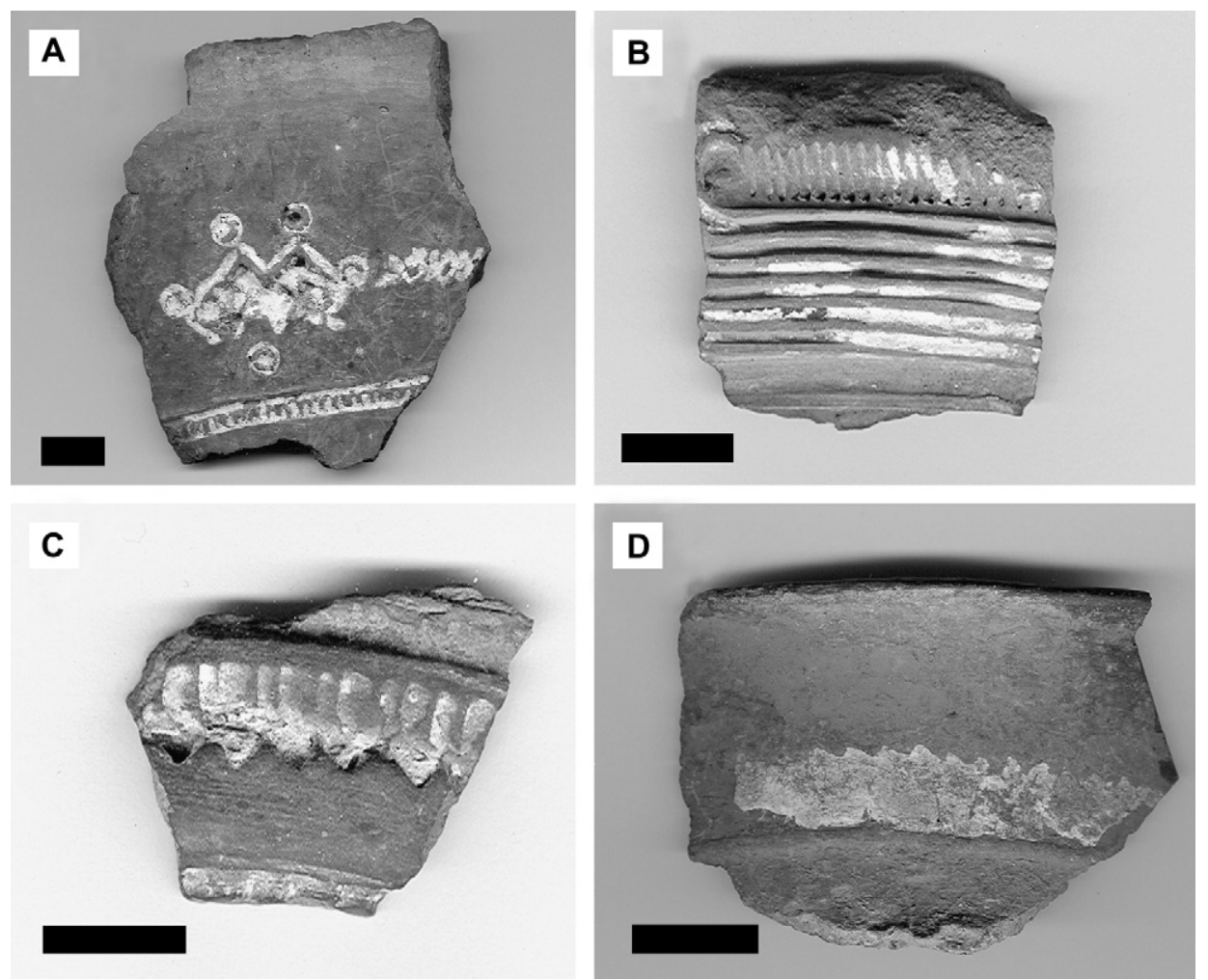

Fig. 2. Examples of fragments of encrusted wares analysed for this study. Black bar indicates $1 \mathrm{~cm}$ scale in all illustrations. (A) Kaposvár-61 (98.101.397/395), (B) Lengyel-Sánc (Sanc 3), (C) Lengyel-Sánc (sr-ls-feb2006), (D) Lengyel-Sánc (Sanc 8). 
inlay material was liberated, mixed with $\mathrm{KBr}$ and pressed into a $3 \mathrm{~mm}$ diameter micro-pellet. Micro-FT-IR spectra were acquired for each sample in the region $600-4000 \mathrm{~cm}^{-1}$ at room temperature and a resolution of $8 \mathrm{~cm}^{-1}$, using a Nicolet Protégé 460 FT-IR spectrometer attached to a Nic-Plan ${ }^{\mathrm{TM}}$ IR microscope. Within this system the IR beam is reflected by a $\mathrm{KBr}$ beamsplitter and focused through the sample onto a liquid nitrogen cooled mercury-cadmium-telluride (MCT) detector; a typical aperture of $100 \mu \mathrm{m} \times 100 \mu \mathrm{m}$ was used to collect spectra. To secure information in the $400-600 \mathrm{~cm}^{-1}$ region additional $8 \mathrm{~mm}$ diameter $\mathrm{KBr}$ pellets were prepared and analysed in the macro chamber of the main bench Nicolet Protégé 460 FT-IR. After a baseline correction the crystallinity of reported apatite spectra was estimated using $\mathrm{CL}=$ $\left(A_{565}+A_{605}\right) / A_{595}$, where $A_{\mathrm{x}}$ is the absorbance at wavenumber $x$ (Termine and Posner, 1996; Shemesh, 1990; Wright and Schwarc, 1996). Carbonate content of measured apatites was calculated using the ratio of the $\mathrm{CO}_{3}\left(1415 \mathrm{~cm}^{-1}\right)$ and $\mathrm{PO}_{4}$ $\left(1035 \mathrm{~cm}^{-1}\right)$ peaks in the sample spectrum and established correlations of $\mathrm{CO}_{3} / \mathrm{PO}_{4}$ absorbance to weight $\% \mathrm{CO}_{3}$ for human skeletons, with a best fit line of $C / P=0.025+$ 0.039 $\left(\% \mathrm{CO}_{3}\right)$ (Wright and Schwarc, 1996).

\subsection{SEM}

In this study SEM was used to examine the texture of inlay samples. Backscattered electron microscope images of pot inlays were completed on a LEO1450 variable pressure SEM equipped with a Princeton Gamma Technology (PGT) energy dispersive X-ray microanalysis system. The SEM operating conditions were $30 \mathrm{kV}$, with a nominal probe current reading of $600 \mathrm{pA}$, and a working distance ranging from between $11 \mathrm{~mm}$ to $19 \mathrm{~mm}$. The pot fragments were left uncoated and the SEM was operated in variable pressure mode (chamber pressure $1 \times 10^{-2} \mathrm{mbar}$ ), using an atmosphere of dry nitrogen gas.

\section{Results}

\subsection{XRD analysis}

X-Ray diffractograms of the white inlay materials from most samples show well-defined and narrow diffraction maxima which correspond to the d-spacing of hydroxyapatite, with some low intensity extraneous peaks attributed to calcite and quartz (Fig. 3, Table 2). As bone mineral is considered to resemble an impure and poorly crystalline form of hydroxyapatite (HAP), with unit cell contents $\mathrm{Ca}_{10}\left(\mathrm{PO}_{4}\right)_{6}(\mathrm{OH})_{2}$ (Mkukuma et al., 2004), these XRD spectra suggest that the inlay material is for the most part mammal bone. Recent studies of the progressive heating of human bone show that the XRD trace shows a marked decrease in band widths between 400 and $600{ }^{\circ} \mathrm{C}$ (Rogers and Daniels, 2002). Similar results were obtained following the progressive heating and XRD analysis of deer antler, with diffraction maxima also becoming significantly more intense and narrow above $600{ }^{\circ} \mathrm{C}$ (Mkukuma et al., 2004).

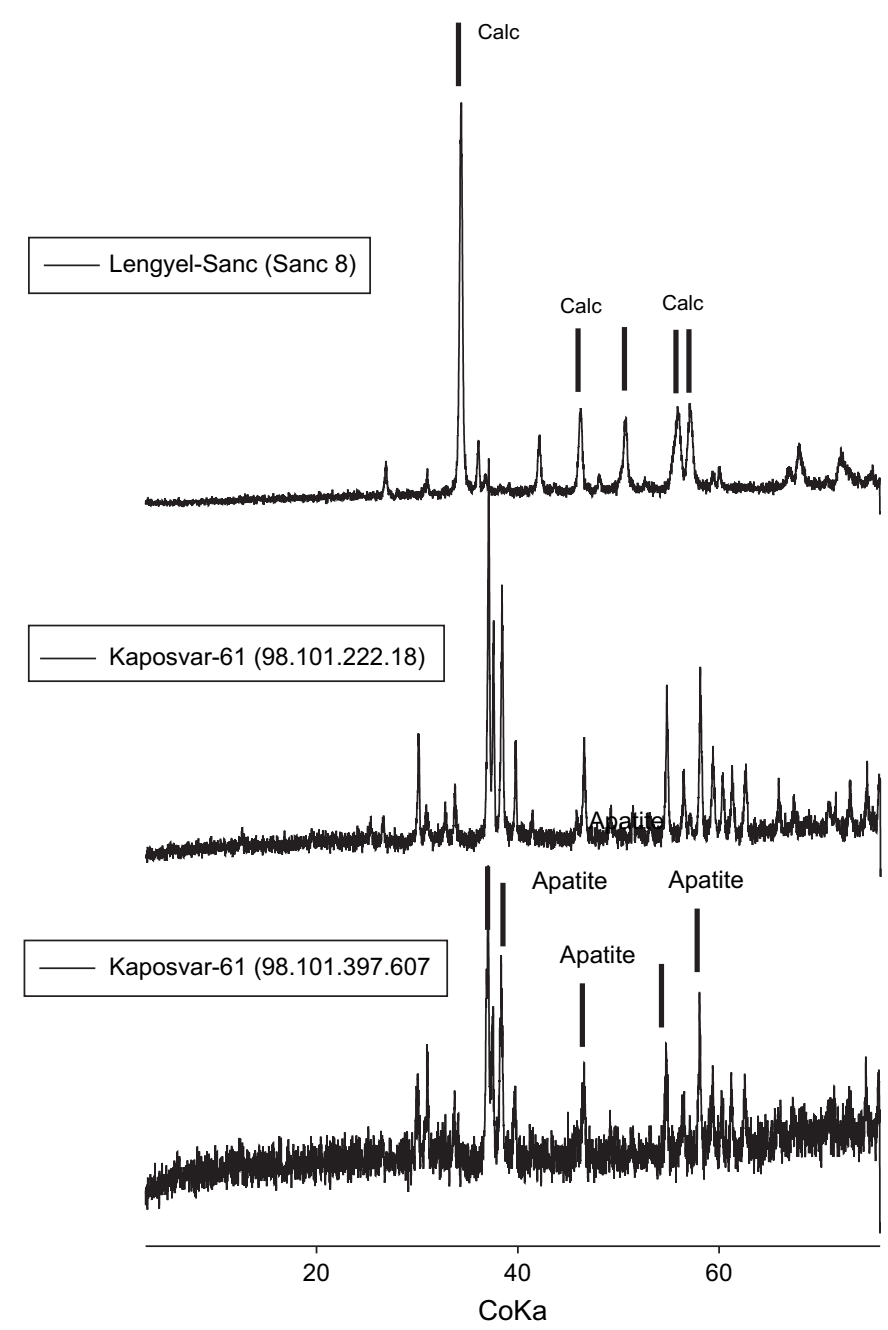

Fig. 3. Examples of XRD spectra determined for white inlay material. Bands attributable to hydroxyapatite and calcite indicated by vertical bars.

In contrast to the XRD traces showing hydroxyapatite, two samples-one analysed from Lengyel-Sánc (Sanc 8) the other from Ménföcsanak-show XRD diffraction maxima which correspond to calcite with traces of dolomite/ankerite (Fig. 3, Table 2). Notably there is no trace of hydroxyapatite in these samples.

XRD traces of the pottery paste show a near uniform composition with maxima attributed to quartz, illite and feldspar, with minor calcite and dolomite (Table 2). This suggests that the clays used in pot fabrication were of near uniform composition. The presence of illite, calcite and lack of calc-silicates or spinels are consistent with firing temperatures of between 600 and $825^{\circ} \mathrm{C}$ (Maritan et al., 2006).

The XRD analyses of inlays and associated pottery paste suggest that although the pot fabrics have a similar mineralogical composition (in line with relatively homogenous surface geology of Transdanubia), and indicating comparable source materials and firing conditions, the inlays show variable composition and comprise either bone apatite or calcium carbonate. These data also show that material collected from the same site can show inlays of contrasting composition. 
Table 2

Summary of mineral species present within inlay and pot matrix following XRD analyses

\begin{tabular}{|c|c|c|c|c|c|c|c|c|c|c|c|}
\hline \multirow[t]{2}{*}{ Sample } & \multirow[t]{2}{*}{ Col } & \multicolumn{4}{|l|}{ Inlay } & \multicolumn{6}{|c|}{ Pot Paste } \\
\hline & & Apatite & Quartz & Calcite & Dol/Ank & Quartz & Illite & Calcite & Dolomite & Plag-Spar & Clinochl. \\
\hline Bonyhád & $\mathrm{R}$ & $\bullet$ & O & & & $\bullet$ & $\bullet$ & o & & o & \\
\hline Ordacsehi (1489/2148) & $\mathrm{O}$ & $\bullet$ & & & & $\bullet$ & $\bullet$ & & & $\bullet$ & \\
\hline Mucsfa A & $\mathrm{O}$ & $\bullet$ & ○ & & & $\bullet$ & $\bullet$ & & & $\bullet$ & \\
\hline Mucsfa B & $\mathrm{R}$ & $\bullet$ & & & & $\bullet$ & $\bullet$ & 0 & & O & \\
\hline Lengyel-Sánc (Sanc 3) & $\mathrm{R}$ & $\bullet$ & & O & & $\bullet$ & O & ○ & O & O & \\
\hline Lengyel-Sánc (Sanc 8) & $\mathrm{R}$ & & ○ & $\bullet$ & ○ & $\bullet$ & $\bullet$ & ○ & O & o & \\
\hline Lengyel-Sánc (Sanc 06) & $\mathrm{O}$ & $\bullet$ & O & & & $\bullet$ & $\bullet$ & & & o & \\
\hline Kaposvár-61(98.101.397.33) & $\mathrm{O}$ & $\bullet$ & O & & & $\bullet$ & $\bullet$ & & & $\bullet$ & \\
\hline Kaposvár-61(98.101.397.25) & $\mathrm{O}$ & $\bullet$ & ○ & & & $\bullet$ & $\bullet$ & $\circ$ & & $\bullet$ & \\
\hline Kaposvár-61(98.101.378.58) & $\mathrm{R}$ & $\bullet$ & & $\circ$ & & $\bullet$ & $\bullet$ & & & $\bullet$ & \\
\hline Kaposvár-61 (98.101.397.607) & $\mathrm{R}$ & $\bullet$ & & & & $\bullet$ & $\bullet$ & & & ○ & \\
\hline Kaposvár-61 (98.101.322.18) & $\mathrm{R}$ & $\bullet$ & O & & & $\bullet$ & $\bullet$ & & & O & \\
\hline Kaposvár-61 (98.101.397.395) & $\mathrm{R}$ & $\bullet$ & & & & $\bullet$ & $\bullet$ & $\bullet$ & & $\bullet$ & \\
\hline Ménföcsanak (obj23) & $\mathrm{R}$ & & & $\bullet$ & $\bullet$ & $\bullet$ & $\bullet$ & & & & $\bullet$ \\
\hline
\end{tabular}

Closed circles represent a strong affirmative XRD response, open circles correspond to a weak potential XRD response.

\subsection{FT-IR}

FT-IR analyses of inlays confirm the XRD analyses and indicate that the majority of inlays show hydroxyapatite spectra, with strong $\mathrm{PO}_{4}$ group bands at $1087 \mathrm{~cm}^{-1}, 1050 \mathrm{~cm}^{-1}$ (v3), $604 \mathrm{~cm}^{-1}$ and $565 \mathrm{~cm}^{-1}(v 4)$ and weak bands at $961 \mathrm{~cm}^{-1}$ (v1) and $472 \mathrm{~cm}^{-1}$ (v2) (Michel et al., 1996) (Fig. 4). The structure of hydroxyapatite permits extensive substitution and non-stoichiometry in the $\mathrm{Ca}, \mathrm{P}$ and channel anions (X) positions (Mackie and Young, 1973; Elliott, 1994; Fleet and Pan, 1995). Carbonate ion located in the apatite channel is referred to as Type A (CAp) whereas carbonate ion substituted for the phosphate ion is Type B (CAp) and each show characteristic IR signatures; Type A has a doublet band at $\sim 1540$ and $1450 \mathrm{~cm}^{-1}$ and a single at $880 \mathrm{~cm}^{-1}$, whereas Type B (CAp) shows bands at $1455+, 1410$ and $873 \mathrm{~cm}^{-1}$ (Fleet et al., 2004). In this study $\mathrm{CO}_{3}$ bands at 1456,1413 and $873 \mathrm{~cm}^{-1}$ suggest that the carbonate ion typically replaces the phosphate ion. The carbonate content for the hyroxyapatite was estimated from the ratio of the absorbances of $\mathrm{CO}_{3}$ at $1413 \mathrm{~cm}^{-1}$ and $\mathrm{PO}_{4}$ at $\sim 1052 \mathrm{~cm}^{-1}$ (Wright and Schwarc, 1996). These data show carbonate content varies between 1.2 and $11 \mathrm{wt} \% \mathrm{CO}_{3}$.

To estimate the crystalline structure of the bone material the crystallinity index (CI) was calculated for each sample. Values range between 2.07 and 3.3 with a strong mode at 2.9 (Fig. 5). These values are towards the high end of those anticipated for fresh bone (SF 2.5-2.9) but are consistent with burned bone (Stiner et al., 1995). Recent measurements of CI with temperature (Surovell and Stiner, 2001) suggest that significant increases in $\mathrm{CI}$ of bone (to a $\mathrm{CI}>4$ ) only occurs after the bone has been subject to temperatures in excess of $600{ }^{\circ} \mathrm{C}$.

Consideration of hydroxyapatite spectra in the $3400 \mathrm{~cm}^{-1}$ region shows contrasting spectra (Fig. 4). Although the majority of spectra show only limited development of bands consistent with the presence of $\mathrm{OH}$ and $\mathrm{H}_{2} \mathrm{O}$ species, other samples (Kaposvár 98.101.322.18), and Lengyel-Sánc (Sanc 3) show bands attributed to $\mathrm{OH}$ species and in the case of sample 98.101.322.18 from Kaposvár additional bands in the 3400$3600 \mathrm{~cm}^{-1}$ region typically attributed to the presence of
$\mathrm{OH}-\mathrm{Cl}$ and $\mathrm{OH}-\mathrm{F}$ species (Dahm and Risnes, 1999; Tacker, 2004) (Fig. 4). One spectra determined from a sample from Lengyel-Sánc (Sanc 3) showed a broad absorption centred on $3400 \mathrm{~cm}^{-1}$ with a strong band at $2900 \mathrm{~cm}^{-1}$ consistent with the presence of molecular $\mathrm{OH}$ and organic material.

The infrared spectra confirmed earlier observations that in two of the samples analysed, Lengyel-Sánc (Sanc 8) and Ménföcsanak (obj23), the inlay appears to solely comprise calcium carbonate with strong bands at 1436,876 and $714 \mathrm{~cm}^{-1}$.

To aid in the interpretation of the inlay spectra a local sample of Bronze Age cremated human bone was analysed by FTIR (Sample G269). This sample shows strong absorptions in the region 1087 and $1050 \mathrm{~cm}^{-1}$, consistent with hydroxyapatite. Notably, the majority of samples from Kaposvár (e.g. 98.101.397.25 and 98.101.397.395) are highly comparable to the cremated bone sample G269 (Fig. 4). However, other samples show contrasting carbonate contents and significant absorptions of energy in the molecular water region, which is not observed in the cremated bone sample. The variable spectral response from the hydroxyapatities may reflect either contrasting starting materials or manufacturing processes.

The FT-IR data confirm that the inlays are predominantly cremated bone, but on occasion calcium carbonate is the prime material used in the inlay.

\subsection{SEM}

Backscattered electron microscope images of selected pot inlays are shown in Fig. 6. Sample (Sanc 3) from the site of Lengyel-Sánc shows an inlay that comprises randomly orientated angular grains of hydroxyapatite, up to $70 \mu \mathrm{m}$ in long dimension (Fig. 6a-c). The grains tend to show a flake-like appearance and are set in a finer grained groundmass, with the local development of cavities within the inlay structure, up to $40 \mu \mathrm{m}$ in long dimension. Spot analysis of grains and groundmass show that both comprise apatite. The high magnification image (Fig. 6c) shows that the groundmass comprises finer fragments of apatite, $<1 \mu \mathrm{m}$ in long dimension, set in a matrix, which is unresolved. Notably, sample Mucsfa B, 


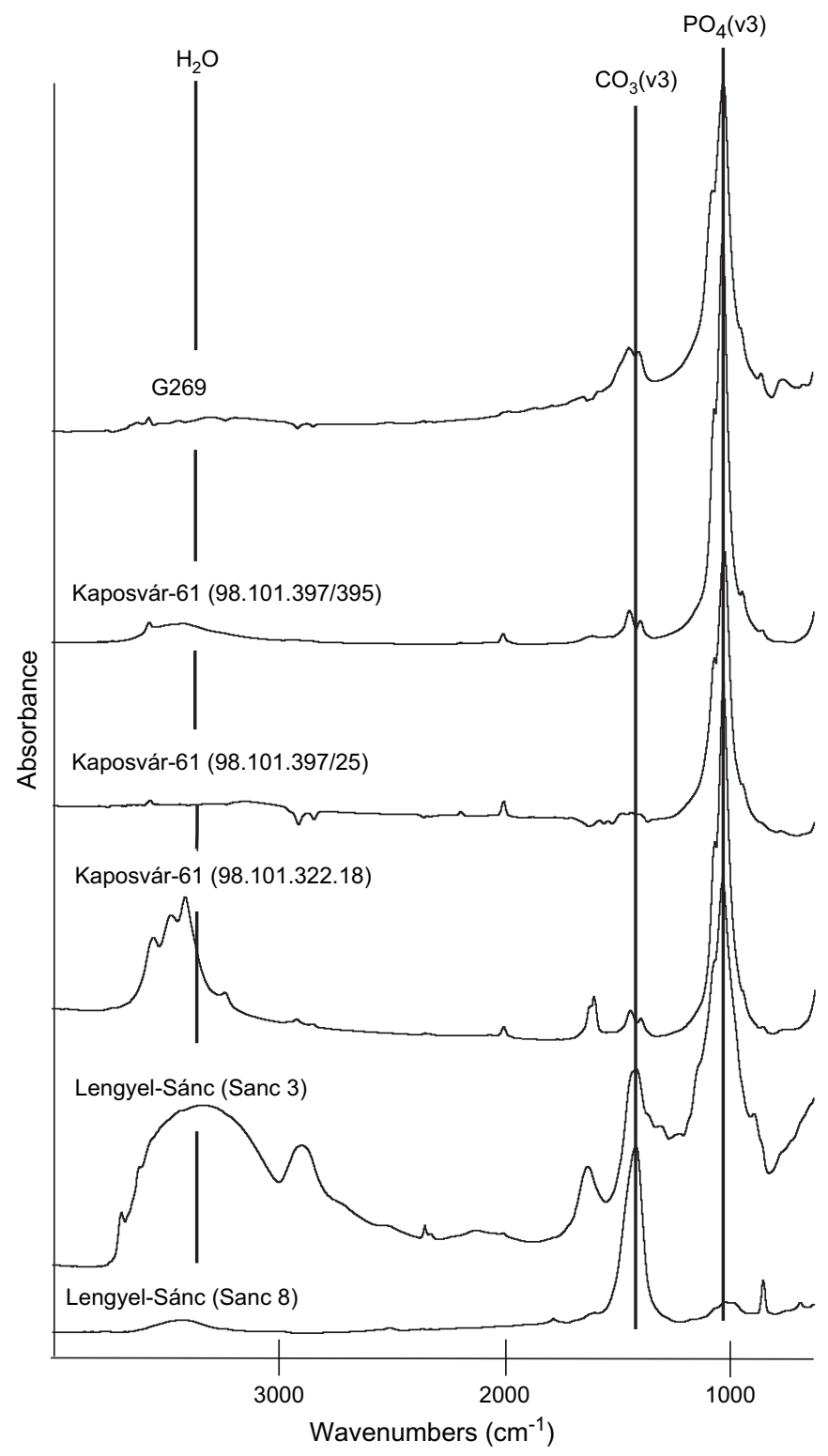

Fig. 4. Examples of FT-IR spectra $\left(600-4000 \mathrm{~cm}^{-1}\right)$ determined for white inlay material. Sample numbers as outlined in Table 2 except G269, which is a sample of Bronze Age cremated human bone.

also shows an hydroxyapatite inlay (Fig. 6d), however, there are notable textural contrasts to the previous sample. In this example the apatite grains are coarser grained and show a blocky appearance, up to $100 \mu \mathrm{m}$ in long dimension (Fig. 6e,f). The matrix to the coarser grains is also less well developed than in the previous sample, but again is composed of apatite, although occasional fragments of a $\mathrm{Ca}, \mathrm{Al}, \mathrm{Fe}, \mathrm{Mg}$ silicate is observed. These contrasting textures suggest that although the inlays are of similar chemical composition, some variations in the initial bone material or sample preparation of the inlay material occurred prior to firing of the vessels.

The sample of carbonate inlay from Ménföcsanak (obj23) is illustrated in Fig. 6g. The sample comprises angular fragments of calcite up to $60 \mu \mathrm{m}$ in long dimension, although the norm is closer to $15 \mu \mathrm{m}$, set in a matrix of finer calcite fragments, with the development of small cavities (Fig. 6h,i).

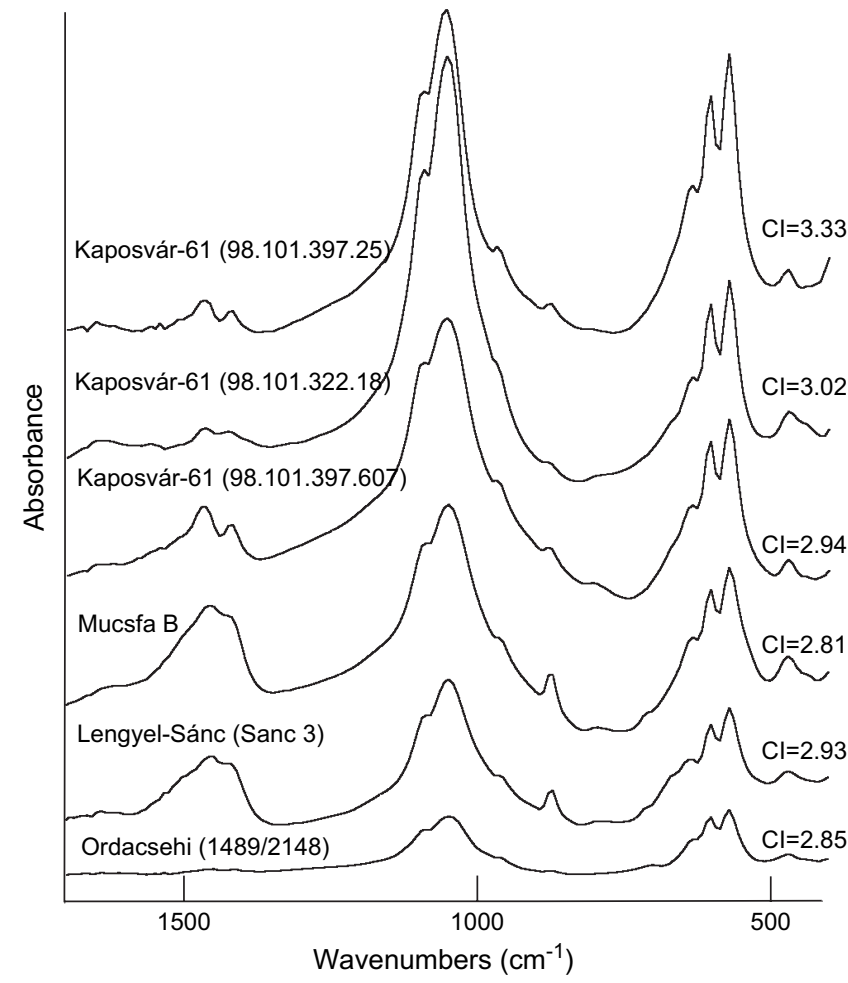

Fig. 5. Examples of FT-IR spectra $\left(400-1800 \mathrm{~cm}^{-1}\right)$ and calculated crystallinity index determined for white inlay materials.

\section{Discussion}

High resolution sampling of inlays followed by XRD and FTIR and SEM analyses confirm that contrasting materials were used in the preparation of the inlays. In the majority of the samples the material employed was hydroxyapatite (bone), while calcium carbonate is present in inlays from contrasting sites and also from sites that also report bone inlays. There is no evidence for the use of birch bark, plant fibres or other materials, nor are the inlays presently composed of lime $(\mathrm{CaO})$, which is a widespread assumption prevalent in the literature (Bóna, 1975; Kiss, 2003). However, given the predicted temperatures of firing $\left(600-825^{\circ} \mathrm{C}\right)$ the presence of calcium carbonate suggests that the inlays were either filled post firing or recarbonated during cooling and subsequent burial. Furthermore, although some of the inlays are calcium carbonate these are not in the majority and the common assertion that inlays are made from crushed shell does not reflect the composition of the inlays analysed for this study.

Despite the relatively small number of samples analysed in this study, both bone and carbonate inlays were found on sherds from sites belonging to northern and southern groups of the Encrusted Pottery Culture. Use of a specific inlay type does not therefore seem to be related to established spatio-typological divisions. Nor is it related to differential access to local resources since the local surface geology of all the sampled sites is very similar, and the composition of the vessel pastes of all the samples are similar. FT-IR and SEM analysis of the inlays also revealed intriguing spectral and textural variation in hydroxyapatite spectra suggesting potential differences in 

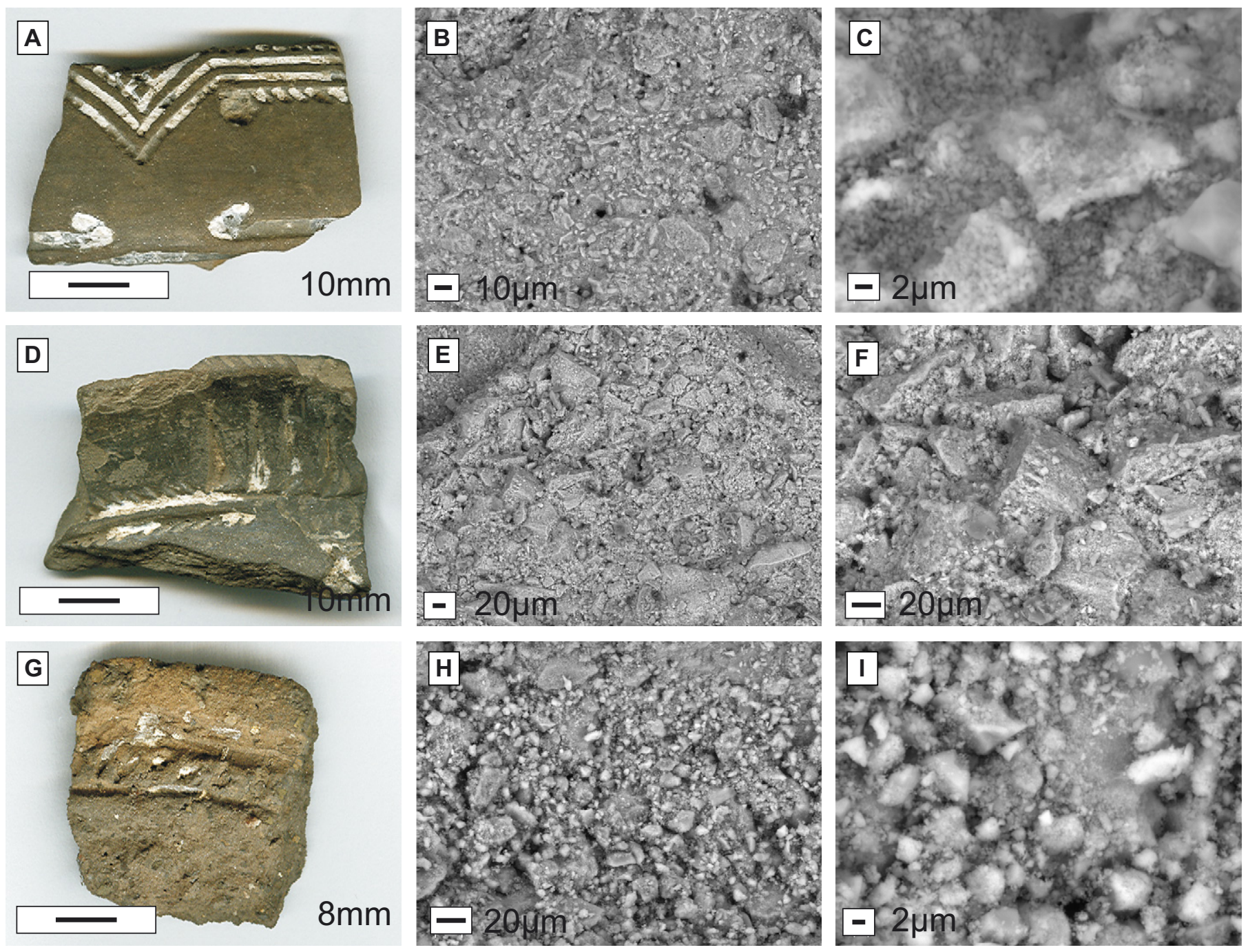

Fig. 6. Examples of pottery sherds with inlays SEM images of white inlay material. (A-C) Sherd with apatite inlay from Lengyel-Sánc (Sanc 3). (D-F) Sherd from apatite inlay from Mucsfa B. $(\mathrm{H}-\mathrm{J})$ Sherd with carbonate inlay from Ménföcsanak.

methods of preparation for the bone inlays. While some samples appear to accurately reflect the FT-IR spectra of the control sample of cremated bone from the same area, other samples show significant variations, in particular the absorption of energy in the hydroxyl region of the infrared.

SEM analyses of the bone material recognised contrasting textures in the two hydroxyapatite samples investigated. This variation may be the result of the use of different species or skeletal elements (diaphyseal vs non-diaphyseal bone) with differing proportions of cortical or cancellous bone (Boskey, 2001; Cattaneo et al., 1999; Jee, 2001; Mayne Correia, 1997). Alternatively, the age of the bone material prior to cremation may have varied. Holden et al. (1995) suggest that the age of the bone on heating (as well as temperature and duration of heating) can influence the morphology of crystals formed and ultrastructural changes, since bone tissue of persons aged between infancy and young adulthood is thermodynamically more unstable than mature bone. At $600{ }^{\circ} \mathrm{C}$ the diameters of spherical-type crystals are significantly smaller in those persons ranging in age from mature adult to old aged, compared with those aged between infancy through to young adult (Holden et al., 1995). This may result in the contrasting textures observed in this study. It is, however, difficult to definitively attribute the differences in the SEM results to either of these explanations. Nor is it currently possible to say whether the bone comes from humans or animals, although given that the most common burial rite of the Encrusted Pottery Culture is cremation our findings raise some intriguing possibilities.

The variability seen in our results suggests that the production of inlaid vessels in Transdanubia during the Middle Bronze Age does not accord with suggestions of the centralised massproduction. Instead it may reflect the existence of a larger number of local workshops and craftspeople and a more fragmented model of production.

\section{Conclusions}

The initial results presented here indicate variability in the characteristics of Middle Bronze Age Transdanubian Encrusted Pottery Culture inlays. By contrast, the pastes used to make the 
vessel walls are very similar in clay, temper and firing temperature. In summary, it has been observed that:

- In contrast to assumptions in the literature that the inlays of the Encrusted Pottery Culture are made of lime, XRD and FT-IR analysis of inlays shows that the most common material used to make inlays is mammal bone, although carbonate-based inlays and mixtures of bone and carbonate were also used.

- There is no evidence for preference for a particular inlay type (either bone or carbonate) in either northern or southern groups of the Encrusted Pottery Culture. Both inlay types can be found in contemporary deposits at individual sites.

- Analysis of bone inlays using SEM revealed variation in the texture of inlays. This may be related to different skeletal elements used to make the inlay and / or the age of bone that was used.

The variability in inlay materials and composition revealed by this study casts doubt on suggestions that Encrusted Pottery Culture vessels were made in centralised workshops situated in well-defined typologically distinct territories of northern and southern groups, and suggests that the production of inlaid vessels was more complex than has previously been assumed. This study is the first step of a wider research programme that will concentrate on obtaining a larger sample of inlays with the aim of exploring the extent of variability, the mode of production, and the basis for technological choices in the production of inlaid vessels in Central and South-East Europe.

\section{Acknowledgements}

We would like to thank Krisztina Somogyi, Dr Andrea Vaday, Dr Magdolna Vicze, the Rippl-Rónai Museum (Kaposvár) and Wosinsky Museum (Szekszárd) for providing access to material and samples for this study. We acknowledge the technical support of Mr Ross Williams in generating the infrared and XRD analyses. Dr Richard Pearce aided production of the SEM images. Prof. David Peacock is thanked for a thoughtful review of the manuscript.

\section{References}

Boskey, A.L., 2001. Bone mineralization. In: Cowin, S.C. (Ed.), Bone Mechanics Handbook, second ed. CRC Press Inc, Boca Raton, FL, pp. 5-1-5-33.

Bóna, I., 1975. Die mittlere Bronzezeit Ungarns und ihre südöstlichen Beziehungen. Archaeologia Hungarica 49. Akadémiai Kiadó, Budapest.

Cattaneo, C., DiMartino, S., Scali, S., Craig, O.E., Grandi, M., Sokol, R.J., 1999. Determining the human origin of burnt bone: a comparative study of histological, immunological and DNA techniques. Forensic Science International 102 (2-3), 181-191.

Csengeri, P., 2001. Adatok a Bükki Kultúra Kerámiamûvességének Ismeretéhez: a Felsõvadász-Várdombi Település Leletanyaga. A Miskolci Herman Ottó Múzeum Évkönyve 40, 72-103.

Dahm, S., Risnes, S., 1999. A comparative infrared spectroscopic study of hydroxide and carbonate absorption bands in spectra of shark enamaloid, shark dentin and geological apaptite. Calcified Tissue International 65, 459-465.

Elliott, J.C., 1994. Structure and Chemistry of the Apatites and Other Calcium Orthophosphates. Elsevier, Amsterdam.

Fischl, P., Kiss, V., Kulcsár, G., 1999. Baks-Homokbánya, kora és középsö bronzkori település a Dél-Alföldön. (Baks-Homokbánya (Kom. Csongrád), eine früh- und mittelbronzezeitliche Siedlung an der Theiss). MFMÉ-Studia Archaeologica V, 77-190.

Fleet, M.A., Liu, X., King, P.L., 2004. Accommodation of the carbonate ion in apatite: An FTIR and X-ray structure study of crystals synthesized at 2-4 GPa. American Mineralogist 89, 1422-1432.

Fleet, M.E., Pan, Y., 1995. Site preference of rare earth elements in fluorapatite. American Mineralogist 80, 329-335.

Gherdan, K., Biró, K.T., Szakmány, Gy., Toth, M. Sólymos. 2003. Analysis of incrusted pottery from Vörs, southwest Hungary, in: Prudêncio, M.I., Dias, M.I., Waerenborogh, J.C. (Eds.), Understanding People Through Their Pottery. Proceedings of the 7th European Meeting on Ancient Ceramics (EMAC'03), pp. 103-108.

Holden, J.L., Phakey, P.P., Clement, J.G., 1995. Scanning electron microscope observations of heat-treated human bone. Forensic Science International 74, 29-45.

Jee, W.S.S., 2001. Integrated bone tissue physiology: anatomy and physiology. In: Cowin, S.C. (Ed.), Bone Mechanics Handbook, second ed. CRC Press Inc, Boca Raton, FL, pp. 1-1-1-68.

Kiss, V., 2002. Anknüpfungspunkte zwischen mitteleuropa und transdanubien in der mittleren bronzezeit. Antaeus 25, 477-511.

Kiss, V., 2003. Potters in Transdanubia. In: Visy, Z. (Ed.), Hungarian Archaeology at the Turn of the Millennium. Ministry of National Cultural Heritage, Budapest, pp. 150-151.

Kiss, V., 2004. Megfigyelések a mészbetétes kerámia kultúrája temetkezési szokásairól és társadalmáról. (Observations on the funerary rites and the society of the Transdanubian Encrusted Pottery Culture). $M \Omega M \Omega \Sigma$ III. Öskoros kutatók III összejövetelének konferenciakötete, pp. 243-266.

Kiss, V., Somogyi, K., 2004. Újabb adatok a Mészbetétes kerámia kultúrája telepeiröl. Elözetes jelentés a Kaposvár-61. út 1. Lelöhely középsö bronzkori településéröl (Recent data on the settlements of Encrusted Pottery Culture: Preliminary report on the Middle Bronze Age settlement of Kaposvár - route 61, site no. 1). M $\Omega M \Omega \Sigma$ II. Öskoros kutatók II összejövetelének konferenciakötete, pp. 93-112.

Mackie, P.E., Young, R.A., 1973. Location of $\mathrm{Nd}$ dopant in fluorapatite, $\mathrm{Ca}_{5}\left(\mathrm{PO}_{4}\right) 3 \mathrm{~F}: \mathrm{Nd}$. Journal of Applied Crystallography 6, 26-31.

Maritan, L., Nodari, L., Mazzoli, C., Milano, A., Russo, U., 2006. Influence of firing conditions on ceramic products: experimental study on clay rich in organic matter. Applied Clay Science 31 (1-2), 1-15.

Mayne Correia, P.M., 1997. Fire modification of bone: a review of the literature. In: Haglund, W.D., Sorg, M.H. (Eds.), Forensic Taphonomy: The Post-Mortem Fate of Human Remains. CRC Press Inc, Boca Raton, FL, pp. 275-293.

Michel, V., Ildefonse, Ph., Morin, G., 1996. Assessment of archaeological bone and dentine preservation from Lazaret Cave (Middle Pleistocene) in France. Palaeogeography, Palaeoclimatology. Palaeoecology 126, 109-119.

Mkukuma, L.D., Skakle, J.M.S., Gibson, I.R., Imrie, C.T., Aspden, R.M., Hukins, D.W.L., 2004. Effect of the proportion of organic material in bone on thermal decomposition of bone mineral: an investigation of a variety of bones from different species using thermogravimetric analysis coupled to mass spectrometry, high-temperature X-ray diffraction and Fourier transform infrared spectroscopy. Calcified Tissue International 75, 321-328.

Rogers, K.D., Daniels, P., 2002. An X-ray diffraction study of the effects of heat treatment on bone mineral microstructure. Biomaterials 23, 2577-2585.

Shemesh, A., 1990. Crystallinity and diagenesis of sedimentary apatites: Geochimica et Cosmochimica Acta 54, 2433-2438.

Šimić, J., 2000. Kulturne skupine s inkrustiranom keramikom u brončanom dobu sjeveroistočne Hrvatske. (Cultural groups with encrusted ceramics in the Bronze Age in north-east Croatia). Academia Scientarum et Artium Croatica, Osijek. 
Stiner, M.C., Kuhn, S.L., Weiner, S., Bar-Yosef, O., 1995. Differential burning, recrystallization and fragmentation of archaeological bone. Journal of Archaeological Science 22, 223-237.

Sümegi, P., Bodor, E., 2000. Sedimentological, pollen and geoarchaeological analysis of core sequence at Tököl, in: Poroszlai, I., Vicze, M. (Eds.), SAX Annual Report 1. Archaeolingua, Százhalombatta, pp. 83-97.

Surovell, T.A., Stiner, M.C., 2001. Standardizing infra-red measurements of bone mineral crystallinity: an experimental approach. Journal of Archaeological Science 28, 633-642.

Sziki, G.Á., Biró, K.T., Uzonyi, I., Dobos, E., Kiss, Á.Z., 2002. Investigation of incrusted pottery found in Hungary by $\mu$-PIXE method. Nuclear Instruments and Methods in Physics Research Section B: Beam Interactions with Materials and Atoms 210, 478-482.

Tacker, C.R., 2004. Hydroxyl ordering in igneous apatite. American Mineralogist $89,1411-1421$
Termine, J.D., Posner, A.S., 1996. Infrared analysis of rat bone: age dependancy of amorphous and crystalline mineral fractions. Science 153, $1523-1525$.

Torma, I., 1978. A balatonakali bronzkori sir. (The Bronze Age grave at Balatonakali). VMMK 13, 15-24.

Trachsler, W., 1966. Precursors of polychrome painted pottery: some examples from the prehistory of Switzerland. In: Matson, F.R. (Ed.), Ceramics and Man. Methuen, London, pp. 152-160.

Uzsoki, A., 1959. Elözetes Jelentés a Mosonszentmiklós-jánosházapusztai Bronzkori Temetö Ásatásának Eredményeiröl. Arrabona 1, 53-73.

Wosinsky, M., 1904. Az Õskor Mészbetétes Díszítésû Agyagmûvessége. Budapest.

Wright, L.E., Schwarc, H.P., 1996. Infrared and isotopic evidence for diagenesis of bone apatite at Dos Pilas, Guatemala: palaeodietary implications. Journal of Archaeological Science 23, 933-944. 